\title{
EN UNDERSØGELSE AF ALLE MENTALOBSERVA- TIONER FORETAGET I HENHOLD TIL DEN GRØNLANDSKE KRIMINALLOV I FEMÅRSPERIODEN 1978-1983
}

\author{
Af Anne Køster og Inge Lynge
}

Som supplement til en mere teoretisk redegørelse for anvendelse af den grønlandske kriminallovs bestemmelser omkring psykisk abnorme lovovertrædere (1) fremlægges en undersøgelse af de mentalobservationer der er foretaget i femårsperioden 1978-1983. Det drejer sig om 88 observationer, hvoraf de 55 er foretaget i Grønland (Dronning Ingrids Hospital) og de 33 på psykiatrisk hospital i Danmark. De to materialer vil blive gennemgået hver for sig med afsluttende sammenligninger samt en samlet status over observandernes retlige stilling $1 \frac{1}{2}$ år efter undersøgelsesperiodens ophør.

\section{Mentalobservationer i Danmark}

Egne undersøgelser.

Metode og materiale.

Samtlige sygejournaler på mentalobservander overført til Danmark i undersøgelsesperioden er gennemgået retrospektivt ud fra oplysning om navn, CPR-nr. og indlæggelsessted i Danmark.

Det drejer sig om Rigshospitalet (RH), Amtshospitalet i Vordingborg (AHV) og Amtshospitalet i Nykøbing Sjælland (ANS), som alle efter aftale med Grønlandsministeriet modtager patienter fra Grønland. Til undersøgelsens udførelse er modtaget et udskrift fra demografisk Institut i Århus indhentet af de involverede afdelinger.

Sigtelser og domme er hentet fra domsudskrifter. Den retlige status på opgørelsestidspunktet, samt oplysninger om tidligere kriminalitet og recidiv efter indekskriminaliteten stammer fra det grønlandske kriminalregister. I 16 tilfælde var der flere alvorlige sigtelser. Den alvorligste er registreret, mens de øvrige er anført i parentes.

Den aktuelle opgørelse er en del af en større undersøgelse, omfattende alle psykiatriske patienter overført fra Grønland til Danmark i samme femårsperiode (2). Denne foretages som led i planlægningen af den fremtidige psykiatriske service i Grønland. Til denne undersøgelse har Kommissionen for videnskabelige Undersøgelser i Grønland givet tilladelse. 
De retslige patienter udgør en $3 / 4$ af hele dette materiale eller 40 patienter. Heraf blev $33(82 \%)$ overflyttet til mentalobservation, mens 7 blev overflyttet $\mathrm{i}$ henhold til dom på grundlag af en tidligere mentalobservation. De er således ikke omfattet af denne undersøgelse.

33 mentalobservationer blev foretaget på 32 patienter i undersøgelsesperioden. 1 patient fik foretaget mentalobservation 2 gange med 2 års interval og taller i undersøgelsen som 2 patienter. 2 patienter i materialet overførtes som arrestanter, men fik senere foretaget mentalobservation. 24 patienter blev observeret på Amtshospitalet i Nykøbing Sjæelland (ANS) heraf fik 2 patienter foretaget ambulant observation, 1 kvindelig patient under anbringelse $\mathrm{i}$ Vestre fiengsel, en mandlig patient var anbragt i Holbrek arrest. 11 patienter fik foretaget observation i Sikringsanstalten, 11 på retspsykiatrisk afdeling. 6 patienter blev observeret på Amtshospitalet i Vordingborg (AHV). 3 patienter på Rigshospitalets psykiatriske afdeling $(\mathrm{RH})$.

Der registreredes $4 \mathrm{I}$ indleggelser, idet 6 patienter var indlagt 2 eller flere gange i undersøgelsesperioden.

Tahel I. Mentalobservation i Danmark af sigtede i henhold til den grønlandske kriminallov 1978-83. Alder og køn.

\begin{tabular}{lrccc} 
& $15-24$ år & $25-44$ år & $45-$ år & I alt \\
\hline Miend & 17 & 12 & - & 29 \\
Kvinder & 4 & - & - & 3 \\
\hline I alt & 21 & 12 & - & 33 \\
\hline
\end{tabular}

Tabel 2. Sigtelse ifølge domsudskrift.

\begin{tabular}{lcc} 
& Mrend & Kvinder \\
\hline Drab & 12 & 1 \\
Drabsforsøg & $9(+1)$ & 2 \\
Vold & 2 & \\
Sexuel kriminalitet mod voksne & $2(+1)$ & \\
Sexuel kriminalitet mod mindreårige & 1 & 1 \\
Trusler på liv & 1 & \\
Ildspåsættelse & $1(+3)$ & $(+1)$ \\
Tyveri & $1(+6)$ & $4(+1)$ \\
Andet & $(+4)$ & \\
\hline I alt & $29(+15)$ & \\
\hline
\end{tabular}


Af tabel 1 fremgår alders- og kønsfordelingen. Det ses, at næsten $2 / 3$ af patienterne er unge mellem 15 og 24 år. Der er i materialet kun 4 kvinder.

Sigtelserne ifølge domsudskrift ses i tabel 2.

26 eller $76 \%$ af observanderne, herunder de 4 kvinder i materialet, havde som hovedsigtelse drab, drabsforsøg eller trusler på livet.

De resterende 7 eller $22 \%$ - alle mænd - havde hovedsageligt voldssigtelser. "Andet« dækker kun bisigtelser som røveri, hærværk, tyveri, ulovlig tvang og omgang med farlige ting. Den alvorligste sigtelse er registreret, mens øvrige er anført i parentes.

Som målestok for hvor tung og kompliceret en sag kan være som resulterer i en kendelse om mentalobservation og for at illustrere, hvilket pres der er på specialafdelinger der udfører observationen, har vi registreret, hvor længe patienterne opholder sig i politiets regie inden overførsel til observation.

Det har ikke været muligt at adskille de enkelte elementer af ventetider politiets efterforskning og ventetiden på indlæggelse på specialafdeling.

27 patienter har ventet i lokal arrest, anstalt samt 12 desuden en del af ventetiden i Herstedvester. Af tabel 3 fremgår det, at knapt halvdelen eller 12 har ventet mere end 3 måneder, og 3 patienter mere end 6 måneder på indlæggelsen til mentalobservation. 22 af de 27 patienter overførtes efter tilbageholdelsen hos politiet til ANS, heraf 11 til Sikringen. 4 patienter overførtes direkte fra psykiatrisk afdeling, Dronning Ingrids Hospital til RH (1 patient) eller AHV (3 patienter). 1 patient overførtes fra kirurgisk afd. DIH som arrestant til RH grundet somatisk sygdom, men blev senere efter kendelse observeret ambulant på ANS.

1 patient overførtes fra lokalt sygehus til AHV ved tvang i henhold til sindssygeloven og fik senere kendelse om mentalobservation.

Tabel 3. Varighed af tilbageholdelse i politiets regie inden indlæggelse til mentalobservation i Danmark.

Antal personer*

$0-1$ måned

4

1-2 måneder

6

$2-3$ måneder

5

3-6 måneder

9

mere end 6 måneder

3

I alt 27

* 26 personer, hvoraf 1 er tilbageholdt og observeret 2 gange i undersøgelsesperioden, hvorfor der er registreret 27 tilbageholdelser. 
Tabe/ 4. Diagnose ved afslutning af observationen (udskrivningsdiagnose).

\begin{tabular}{lrcr} 
& Mand & Kvinder & I alt \\
\hline Skizofreni & 2 & 1 & 3 \\
Manio depressiv psykose & 1 & & 1 \\
Personlighedsforstyrrelser & 24 & 2 & 26 \\
Alkoholisme & 2 & 0 & 2 \\
Inferioritas intellectualis & & 1 & 1 \\
\hline I alt & 29 & 4 & 33 \\
\hline
\end{tabular}

I tabel 4 ses hoveddiagnose ved udskrivning. Ca. $4 / 5$ eller 26 patienter havde hoveddiagnosen personlighedsforstyrrelser. 3 skizofreni, 1 manio depressiv psykose. Kun 2 patienter havde alkoholisme som hoveddiagnose, men et flertal af patienterne havde alkoholmisbrug i lettere eller sværere grad (i anamnesen) som bidiagnose.

Ifølge tabel 5 modtog 22 eller $70 \%$ af observanderne - alle mænd - en »anstaltsdom«, idet 13 fik tidsubestemt dom til Herstedvester, 9 tidsubestemt dom til grønlandsk anstalt. 5 (3 mænd og 2 kvinder) fik tilsyn og eventuelt også påbud om spiritusafvænningsbehandling under den grønlandske kriminalforsorg. Dom til anbringelse eller behandling i egentlig hospitalsregie blev kun anvendt i 5 tilfælde, heraf fik to skizofrene mænd en sikringsdom. 1 observand blev aktuelt frikendt, men fik iværksat en tidligere pådømt anstaltsdom i Grønland.

Ingen fik tidsubestemt dom til anstalt i Grønland.

Tabel 5. Efter afsluttet mentalobservation blev der afsagt følgende domme til foranstaltning.

\begin{tabular}{llll} 
Krend & Kvinder \\
\hline
\end{tabular}

Dom til sikringsanstalt

Dom til anbringelse på psykiatrisk hospital

Dom til behandling på psykiatrisk hospital

Dom til anbringelse på anstalten i Herstedvester

Dom til anstalt i Grønland

Dom til kriminalforsorg i Grønland

Frifindelse

\begin{tabular}{rl}
2 & - \\
- & 1 \\
1 & 1 \\
13 & - \\
9 & - \\
3 & 2 \\
1 & - \\
\hline
\end{tabular}

29
4 


\section{Mentalobservationer i Gronland}

Egne undersøgelser.

Metode og materiale.

Samtlige mentalobservationer i Grønland er foretaget af overlægerne ved psykiatrisk afdeling ved DIH eller andre speciallæger ansat $\mathrm{i}$ afdelingen. Alle observationserklæringerne er gennemgået og sigtelser og domme for de pågældende er hentet fra domsudskrifter. Den retlige status på opgørelsestidspunktet er oplyst fra det grønlandske kriminalregister. Mentalobservationer blev foretaget på 55 personer i den femårige undersøgelsesperiode. Deres køn og alder fremgår af tabel 6. Sigtelserne fremgår af tabel 7.

Tabel 6. Mentalobservationer i Grønland 1978-83. Køn og alder.

\begin{tabular}{lrrcc} 
& $15-24$ år & $25-44$ år & $45-$ år & I alt \\
\hline Mænd & 16 & 24 & 2 & 42 \\
Kvinder & 5 & 8 & - & 13 \\
\hline I alt & 21 & 32 & 2 & 55 \\
\hline
\end{tabular}

Tahel 7. Sigtelse ifølge domsudskrift for patienter observerede i Grønland.*

\begin{tabular}{lcc} 
& Mænd & Kvinder \\
\hline Drab & 11 & 5 \\
Drabsforsøg & $12(+2)$ & 8 \\
Vold & $4(+5)$ & \\
Sexuel kriminalitet mod voksne & $5(+3)$ & \\
Sexuel kriminalitet mod mindreårige & $3(+4)$ & \\
Incest & $1(+2)$ & \\
Omgang med farlige ting (skyderi m.v.) & $1(+1)$ & \\
Tyveri, trusler m.m. & 1 & \\
\hline I alt & $42(+17)$ & 13 \\
\hline
\end{tabular}

* I 17 tilfælde var der flere alvorlige sigtelser. Den alvorligste er registreret, mens de øvrige er anført i parentes.

Man bemærker, at de observerede kvinder alene er sigtet for drab og drabsforsøg, mens næsten halvdelen af mændenes sigtelser vedrører andre forbrydelser, først og fremmest sexuel kriminalitet.

For de 42 mænd var der i 17 tilfælde tale om flere alvorlige sigtelser. De alvorligste sigtelser er registreret, mens øvrige er anført i parentes. 
Alle 13 kvinder blev observeret under indlæggelse på Dronning Ingrids Hospitals psykiatriske afdeling. 19 af de 42 mænd blev ligeledes observeret under indlæggelse, de øvrige ambulant mens de var tilbageholdt $\mathrm{i}$ arresten $\mathrm{i}$ Nuuk eller i anstalten for domfældte.

Diagnoser fremgår af tabel 8.

Tabel 8. Diagnose ifølge mentalobservation for patienter observerede i Grønland.

\begin{tabular}{lcc} 
& Mænd & Kvinder \\
\hline Skizofreni & 1 & - \\
Reaktiv psykose & 2 & 2 \\
Personlighedsforstyrrelser & 19 & 5 \\
Alkoholisme & 10 & - \\
Forbigående forstyrrelser & 2 & 4 \\
Organisk skade & 4 & 1 \\
Inferioritas intellectualis & - & 1 \\
Intet psykisk abnormt & 4 & - \\
\hline I alt & 42 & 13 \\
\hline
\end{tabular}

For de indlagte er udskrivningsdiagnosen anvendt. For de ambulante observationer er der ikke altid i erklæringen anført en explicit diagnose. På grundlag af beskrivelsen i erklæringen har en diagnose kunne formuleres.

5 har været psykotiske på gerningstidspunktet. Heraf har de 4 haft reaktive psykoser mens 1 lider af skizofreni. $1 / 4$ af mændene har alkoholisme som væsentligste problem. I 4 tilfælde har der ikke kunnet konstateres nogen psykisk abnormitet. Hos 4 kvinder har der været tale om forbigående forstyrrelser affektreaktioner - hos i øvrigt psykisk upåfaldende kvinder.

Tabel 9. Foranstaltning for patienter observerede i Grønland.

\begin{tabular}{lrc} 
& Mænd & Kvinder \\
\hline Dom til sikringsanstalt & - & - \\
Dom til anbringelse på psykiatrisk hospital i Danmark & 2 & - \\
Dom til behandling på psykiatrisk hospital i Danmark & 1 & - \\
Dom til Herstedvester & 1 & - \\
Dom til anstalt (heraf ubestemt tid 2) & 30 & 1 \\
Dom til kriminalforsorg + psykiatrisk behandling i Grønland & 1 & 2 \\
Dom til kriminalforsorg i Grønland & 7 & 10 \\
\hline I alt & 42 & 13 \\
\hline
\end{tabular}


Af tabel 9 ses, at $60 \%$ eller 32 af observanderne idømtes anstalt i Grønland, heraf 2 på ubestemt tid - hvilket senere, såfremt sikkerhedshensyn taler herfor, kan ændres til en Herstedvesterdom ifølge $\S 104$ stk. 2. Dette blev dog ikke tilfældet. En kvinde idømtes for første gang i Grønland en anstaltdom. Ca. $30 \%$ eller 16 - heraf $2 / 3$ kvinder - idømtes tilsyn af kriminalforsorgen samt eventuel spiritusafvænningsbehandling. Kun 4 observander modtog domme, som krævede overflytning til Danmark.

\section{Sammenligning af grupperne observeret henholdsvis i Gronland og Danmark}

De to grupper der observeres henholdsvis i Grønland og i Danmark viser ikke markante forskelle med hensyn til de sigtelser der medførte observationen. Der er i alle tilfælde tale om alvorlige sigtelser. En gennemgang af de enkelte sager viser dog at der observeredes flere i Danmark med bizar og umiddelbart uforståelig kriminalitet - f.eks. drab uden åbenbart motiv eller udført på en brutal eller sær måde. I enkelte tilfælde har overflytning til Danmark været nødvendig for at få en effektiv adskillelse mellem gerningsmand og offer, når kriminaliteten er udsprunget af en langvarig ophobet affekt, og der var risiko for gentagelser.

Tabel 10. Tidligere kriminalitet (tilførsler til det grønlandske kriminalregister) før den sigtelse, der udløste mentalobservation.

Observeret Observeret

i Grønland i Danmark

Ingen

Mindre alvorlig - enkelte forhold

Mindre alvorlig - mange forhold

Alvorlig kriminalitet

7

6

$19-5$

Alvorlig kriminalitet

I alt 55

Tabel 11. Tidligere foranstaltninger (kun den mest indgribende er anført).

Observeret Observeret

i Grønland i Danmark

Behandling psykiatrisk hospital

Anstalt for domfaldte

4

5

25

17

Ungdomspension

Kriminalforsorg

15

6

$-$

13

5

I alt

24

20 
De fleste observander har tidligere kriminelle forhold, for ca. halvdelens vedkommende drejer det sig om alvorlig og ofte gentagen kriminalitet (tabel 10). En gennemgang af tidligere idømte foranstaltninger tyder på at de der observeredes i Danmark var mere belastede, i hvert fald har de flere anstaltsdomme se tabel 11. Kun den mest indgribende foranstaltning er anført. De fleste med dom til anstalt har også tidligere haft mindre indgribende foranstaltninger.

De 15 med tidligere anstaltsdomme, som er observeret i Danmark har haft i alt 37 tidligere anstaltsdomme, heraf har de 2 været anbragt i anstalt i Grønland 5 gange tidligere. 1 har kortvarigt været overført til Herstedvester.

De 6 med tidligere anstaltsdomme, som er observeret i Grønland har haft i alt 14 domme til anstalt, heraf tegner 2 sig for hver 4 domme til anstalt.

Af $\mathrm{i}$ alt 75 observander med tidligere kriminalitet har 65 været idømt $\mathrm{i}$ alt 238 bøder. »Rekorden« er 19 tidligere bøder til en mand, som blev observeret i Grønland.

Hvorledes er det gået observanderne efier undersogelse og domfaldelse? Tabel 12 viser forekomsten af recidiv. Foranstaltningen på recidivtidspunktet er ligeledes anført.

Tabel 12. Ny kriminalitet begået efter mentalobservation.

Foranstaltning på Observeret i

Observeret $\mathrm{i}$

gerningstidspunktet

Grønland $\mathrm{n}=55$

Danmark $n=32$

Alvor- Mindre

Alvor- Mindre

lig alvorlig

lig alvorlig

Anbr. Herstedvester

$0 \quad 0$

Ophold psykiatrisk hospital i Danmark

Anstalt i Grønland

Kriminalforsorg i Grønland

- (udgået af foranstaltning)

$0 \quad 0$

20

46

39

I alt

9

15

8

Der er i alt 17, der har begået alvorlig recidivkriminalitet og 25 mindre alvorlig. Der er tale om en skønsmæssig opdeling. Tyverier, hærværk, lettere voldssager, dokumentfalsk, spirituskørsel etc. er henregnet til lettere recidiver, mens drab og drabsforsøg, røveri (en betegnelse der dog kun findes i den danske straffelov, og således refererer til recidiv begået i Danmark), grov vold, voldtægt, incest, ildspåsættelse etc. henregnes til alvorlig kriminalitet. 
Blandt de i Danmark observerede har $25 \%$ haft alvorligt recidiv, i 1 tilfælde drab og 1 drabsforsøg. Blandt de i Grønland observerede har $16 \%$ haft alvorligt recidiv, heraf 1 drab og 1 drabsforsøg.

Tabel 13 viser den retlige status på opgørelsestidspunktet 1. juli 1984. De i Grønland observerede klarede sig bedst. 31 (56 \%) var recidivfri på opgørelsestidspunktet og heraf var 20 (36\% af alle observerede) helt ude af foranstaltningen, mens 4 fortsat var under kriminalforsorg og 4 i anstalt i Grønland. Af de i Danmark observerede var $14(44 \%)$ recidivfri, men heraf var kun 2 (6\% af alle observerede) ude af foranstaltning. 6 var fortsat anbragt i Herstedvester, $1 \mathrm{i}$ Sikringsanstalt. Blandt de i alt 10, som på opgørelsestidspunktet befandt sig $\mathrm{i}$ Herstedvester, havde 4 således haft alvorligt recidiv, heraf havde den ene begået røverier under flugt fra Herstedvester. En anden havde begået alvorlig kriminalitet i Danmark under flugt fra psykiatrisk hospital, mens de 2 sidste havde haft dom til anstalt i Grønland og her begået den alvorlige recidivkriminalitet.

Tabel 13. Retlig status ved efterus. 1/7 1984 .

Observeret

Observeret

i Grønland

i Danmark

\begin{tabular}{lrrrrrrrr}
\hline \multirow{2}{*}{ Foranstaltning } & \multicolumn{4}{c}{ Recidiv } & \multicolumn{5}{c}{ Recidiv } \\
& + & $(+)$ & $\div$ & I alt & I alt & $\div$ & $(+)$ & + \\
\hline Ingen & 0 & 13 & 20 & 33 & 8 & 2 & 5 & 1 \\
KF & 4 & 2 & 4 & 10 & 4 & 1 & 3 & - \\
Anstalt i Grønland & 3 & 0 & 4 & 7 & 4 & 0 & 1 & 3 \\
Herstedvester & 0 & 0 & 0 & 0 & 10 & 6 & 0 & 4 \\
Ophold psykiatrisk hospital & 0 & 0 & 0 & 0 & 0 & 0 & 0 & 0 \\
Behandling psyk. hospital & 0 & 0 & 0 & 0 & 4 & 3 & 1 & 0 \\
Sikringsanstalt & 0 & 0 & 0 & 0 & 1 & 1 & 0 & 0 \\
Død & 2 & 0 & 3 & 5 & 1 & 1 & 0 & 0 \\
\hline I alt & 9 & 15 & 31 & 55 & 32 & 14 & 9 & 8 \\
\hline
\end{tabular}

$(+)$ Recidiv $=$ mindre alvorligt

+ Recidiv $=$ alvorligt recidiv .

I alt 6 af observanderne er døde. 1 (i Danmark observeret) begik selvmord i Sikringsanstalten. Af 5 observeret i Grønland er 1 blevet dræbt efter beruset at have provokeret gerningsmanden. 1 er omkommet ved trafikulykke (beruset). 2 begik selvmord, den ene efter at være anbragt $\mathrm{i}$ isolationscelle $\mathrm{i}$ beruset tilstand. 1 døde af blodprop i hjertet. 


\section{De kvindelige observander}

En rakke forhold adskiller de kvindelige observander fra de mandlige, således at de kommer til at udgøre en særlig gruppe ikke blot i kraft af deres køn, men også som følge af selve kriminalitetsmønstret og forløbet.

Kvinderne er en minoritet. De udgør $20 \%$ af samtlige observander - $12 \%$ af dem der observeres i Danmark.

Kvinderne har drab, drabsforsøg og $\mathrm{i}$ et enkelt tilfælde trusler som hovedsigtelse og har sjældent flere sigtelser, mens mændenes kriminalitet tillige er preget af varierende grader af vold, sexuelle overgreb og berigelseskriminalitet. Mandene har ofte en kriminel »karriere«, mens kvinderne mest ses optræde $i$ en enkeltstående sag. Under halvdelen af kvinderne har tidligere kriminalitet og da udelukkende af mindre alvorlig karakter. Sædvanligvis er offeret eller den indirekte årsag til den begåede kriminalitet en mand som er at finde inden for den nærmeste familie. Det være sig ægtefælle, samlever eller tidligere samlever, bror eller onkel. De fleste kvinder har lever under svært og langvarigt pres uden mulighed for at bryde ud, ofte under voldelige forhold, hvor forbrydelsen bliver den desperate kulmination. Undertiden synes det at bero på et tilfæelde, at det ikke er kvinden, der bliver offeret.

Vor opgørelse drejer sig i 11 tilfielde om drab eller drabsforsøg mod samlever, agtefielle, bror, fader eller onkel. I 2 tilfæelde begik kvinden drabsforsøg mod eget mindreårigt barn. 1 begge tilfæelde påvistes en reaktiv depressiv tilstand på gerningstidspunktet, hvor kvinden havde suicidale forestillinger.

I det ene tilfælde angav moderen at hun af medlidenhed med barnet ønskede at tage det med sig i døden. I det andet tilfielde skete der en kortslutning, idet den suicidale impuls blev vendt til aggression mod barnefaderen og barnet blev offer herfor.

I 2 tilfælde foretog kvinder drabsforsøg mod tilsyneladende tilfældige mænd. I et tilfælde havde kvinden forinden forsøgt at skyde sin broder, men kunne ikke få skudet til at gå af, og rettede så riflen mod den netop tilstedekomne politibetjent. I det andet tilfælde stak en kvinde uden motiv en kniv i brystet på en drikkekammerat.

En kvinde stak ild til en anden kvinde som følge af jalousi - grundet deres forhold til samme mand. Endelig fremsatte en kvinde drabstrusler mod en læge på grund af fejlbehandling. Alle kvinder var i varierende grad under alkoholpåvirkning da de begik deres kriminalitet. Alkoholpåvirkningen har utvivlsomt banet vej for den kriminelle handling, men kun i 3 tilfæelde synes den at have haft afgørende betydning. 2 af disse kvinder havde et langvarigt alkoholmisbrug, alle 3 var under udførelsen af forbrydelsen svært berusede, 1 af kvinderne blev opfattet som værende $\mathrm{i}$ en patologisk rus.

I kvindegruppen synes selve mentalobservationen at have haft karakter af 
krisebehandling med en vis afklaring og indsigt til følge. Kun 3 ( 1 observeret $\mathrm{i}$ Danmark og 2 observeret i Grønland) har haft recidivkriminalitet, den ene af alvorligere karakter, hvorefter et ophævet vilkår om psykiatrisk behandling blev genetableret. 3 af de i Danmark observerede og 2 af de i Grønland observerede kvinder er under foranstaltning på opgørelsestidspunktet.

De øvrige 12 er uden foranstaltning, og man må generelt sige, at det er.gået dem godt.

\section{Diskussion}

Formålet med denne opgørelse har først og fremmest været at få et overblik over den hidtidige praksis for det retspsykiatriske arbejde $\mathrm{i}$ og for Grønland. Dernæst at påpege åbenbart utilfredsstillende forhold som konsekvens af denne praksis. Målt $\mathrm{i}$ antal sigtelser er det en ganske lille del af den begåede kriminalitet der er omfattet af undersøgelsen. Der afhøres årligt ca. 4.000 sigtede. Blandt dem blev i hele undersøgelsesperioden i alt 620 tilbageholdt efter grundlovsforhør. Heraf blev $14 \%$ mentalobserveret, de $9 \%$ i Grønland og $5 \%$ i Danmark. Der er foretaget mentalobservation i $60 \%$ af drabssigtelser, knap 30 $\%$ af sigtelser for drabsforsøg, $4 \%$ af sigtelser for sædelighedsforbrydelser og $1 / 2$ $\%$ af voldssigtelser.

Allerede ved beslutningen om observation i Danmark eller Grønland sker der en skønsmæssig vurdering af observandens farlighed og af sandsynligheden for behov for foranstaltning i Danmark. Godt $1 / 2$ af de i Danmark observerede får da også dom til foranstaltning i Danmark, mens det kun gælder 1/14 af de i Grønland observerede.

$\mathrm{Nu}$ er de omstændigheder, hvorunder mentalobservationer foretages henholdsvis i Grønland og Danmark meget forskellige. Man må også nære betænkelighed ved de lange ventetider for observation i Danmark. Dels er ventetiden i sig selv belastende for den sigtede, dels må observationen vanskeliggøres af at skulle foretages måske $1 / 2$ år efter den påsigtede gerning.

Udfra et retssikkerhedsmæssigt synspunkt ville det være mere tilfredsstillende, såfremt observationerne kunne ske under mere ligeartede forhold, hvorved præmisser og konklusioner var mere direkte sammenlignelige.

Det ser ud til at vurderingen af, hvem der har behov for psykiatrisk hospitalsbehandling er ret sikker. I hvert fald får. kun 2 med oprindelig dom til Herstedvester senere domsændring til psykiatrisk hospital. Den ene begår alvorlig kriminalitet under bortgang fra hospitalet og tilbageflyttes herefter til Herstedvester. Kun een med oprindelig dom til psykiatrisk foranstaltning har begået recidivkriminalitet.

Hvad der må give anledning til yderligere overvejelser er anvendelsen af dom til »psykiatrisk ledet anstalt under kriminalforsorgen i Danmark«. Formulerin- 
gen dækker ikke længere de faktiske forhold, idet anstalten ved Herstedvester, som tidligere har haft psykiatrisk ledelse, nu har status som et fængsel, ledet af en fængselsinspektør. For de personer der anbringes $\mathrm{i}$ henhold til den grønlandske kriminallov skal ledelsen udøves af fængselsinspektør og overlæge i fællesskab.

Denne dom anvendes som en sikkerhedsmæssig og overvejende socialpædagogisk foranstaltning for ikke psykotiske sværere psykisk afvigende personer.

Vurderingen af, hvornår en person af denne gruppe anses for uegnet til anbringelse $\mathrm{i}$ anstalt $\mathrm{i}$ Grønland eller vurderingen af, hvorvidt en sådan anbringelse giver tilstrækkelig sikkerhed, er naturligvis skønsmæssig.

Psykiatriens beskrivelse og vurdering af gradvise overgange mellem fænomenerne støder her sammen med juraens dikotomier. Selv om der næppe er stor forskel på den vurderede farlighed mellem den farligste i gruppen, der får dom til anstalt i Grønland og den mindst farlige af dem, der får dom til Herstedvester, får det store konsekvenser, hvilken »bås« den enkelte placeres i.

Med dom til Herstedvester vil det være yderst vanskeligt at lempe på sikkerhedsforanstaltningerne med henblik på en gradvis overgang til det almindelige samfund, først og fremmest på grund af den fysiske afstand til det hjemlige miljø og de alt for få ressourcer, der er til rådighed til besøgsrejser etc. Således som systemet fungerer skal den domfældte kunne klare sig efter den bratte overgang fra fængselsmiljø til helt frie forhold, hvilket kunne medføre at man beholder ham længere for at være på den sikre side. Det grønlandske anstaltssystem har mulighed for at fungere på en langt mere smidig måde med henblik på lempelse af foranstaltninger og tilbageslusning til samfundet. Den domstol, der skal træffe beslutningen om prøveløsladelse eller overførsel til en grønlandsk anstalt vil også være påvirket af den understregning af den domfældtes potentielle farlighed der ligger i selve dommen til Herstedvester.

\section{Hvorledes kan vi forholde os til disse problemer?}

Vi ønsker ikke at bagatellisere den meget alvorlige kriminalitet eller den potentielle farlighed hos den enkelte, (uanset om han foranstaltes i Grønland eller Danmark), men vi vil påpege at $\mathrm{i}$ og med, at der sker en så definitiv opdeling af de ikke psykotiske psykisk afvigende domfældte bliver synet på den enkelte præget af, i hvilken gruppe han er placeret.

Taget med visse forbehold - vel vidende, at man overføre et tungere belastet klientel til Danmark - synes det alligevel bemærkelsesværdigt at kun 1/4 af denne gruppe mod $3 / 5$ af den gruppe der observeres i Grønland er ude af foranstaltning ved efterundersøgelsen i 1984. Dog er antallet af recidiver, også alvorlige, betydeligt blandt dem der er observeret i Grønland. Man făr det indtryk at tærskelen for at sende en sigtet til mentalobservation i Danmark er høj, netop 
fordi konsekvensen af dom til en foranstaltning i Danmark er så alvorlig. Men omvendt er ængstelsen for at hjemtage en domfældt fra Herstedvester tilsvarende stor og der er fare for at systemet stivner.

Vurderingen af den enkelte domfældtes farlighed er meget vanskelig. Der er jo ikke tale om en stabil egenskab hos den enkelte person, men om et samspil af faktorer, som kan øge, respektive nedsætte risikoen for ny kriminalitet.

Den nuværende grønlandske kriminallov giver ikke mulighed for at opstille særlige betingelser i forbindelse med dom til anstalt i Grønland. Der er intet i loven der direkte opmuntrer til at øge mulighederne for at integrere psykisk abnorme lovovertrædere i det grønlandske foranstaltningssystem. Det eneste der kunne tale herfor er bestemmelsen i § 104. Tvivl om en sigtet med psykisk abnormitet vil kunne klare sig i en grønlandsk anstalt kan med denne bestemmelse komme en sigtet til gode, idet en dom til anstalt på ubestemt tid vil kunne ændres til Herstedvester uden at den pågældende har begået ny kriminalitet.

I undersøgelsesperioden har $\mathrm{i}$ alt 20 personer været indsat i Herstedvester efter dom ifølge den grønlandske kriminallov, heraf indgår de 15 personer i vor undersøgelse, mens de 5 har været mentalobserveret tidligere. 3 af dem har i øvrigt også tidligere haft dom til Herstedvester.

Kun 1 af disse 20 personer blev overflyttet på grundlag af bestemmelsen i $\S$ 104.

I alle andre tilfælde var grundlaget for dom til Herstedvester en ny alvorlig kriminalitet, og beslutningen herom skete tilsyneladende uafhængigt af, om han i forvejen havde tidsubestemt dom til anstalt i Grønland.

Giver denne undersogelse anledning til at pege på mulige forbedringer af foranstaltningssy'stemet for psykisk abnorme lovovertradere i Gronland?

For det første bør mulighederne for at foretage mentalobservation i Grønland forbedres, således at kun de observationer, der foretages på Sikringsanstalten fortsat behøver at foregå i Danmark. I undersøgelsesperioden har der gennemsnitligt været 2 observationer årligt på Sikringsanstalten og 4 på andre psykiatriske afdelinger, overvejende den retspsykiatriske afdeling i Nykøbing Sj. Hvis der etableres en lukket afdeling i Grønland og der er tilstrækkelig undersøgelseskapacitet kunne de sidstnævnte observationer lige så vel foretages $\mathrm{i}$ Grønland. Det bør dog fortsat være adgang til observation i Danmark i særlige tilfælde.

Men også foranstaltningsfasen kan der sættes focus på. En stigende del af dommene til ophold eller behandling på psykiatrisk hospital kunne fuldbyrdes i Grønland forudsat der sker en udbygning af den psykiatriske service som nævnt ovenfor. 
Det ser ud til at ca. $2 / 3$ af dem der idømtes anstalt i Grønland klarer sig rimelig godt, mens en mindre del både blandt dem der har været observeret $\mathrm{i}$ Grønland og i Danmark har betydelige problemer, herunder recidiv-kriminalitet under eller efter anstaltsopholdet.

En oprustning af anstalterne så arbejdet med disse klienter kunne intensiveres ville også kunne bane vej for en hjemtagning af flere fra Herstedvester.

Med oprustning tænker vi både på alternative foranstaltninger som led $\mathrm{i}$ et foranstaltningsforløb, mulighed for beskæftigelse $\mathrm{i}$ anstalterne, når der er behov for det, undervisning og træning af sociale færdigheder etc. Det må også overvejes om der igen bør kunne fastsættes vilkår om psykiatrisk behandling $\mathrm{i}$ forbindelse med dom til anstalt i Grønland.

For dem der har dom til Herstedvester bør der umiddelbart ske en forbedring af muligheden for besøgsrejser til Grønland, for at understrege og fastholde det endelige mål for foranstaltning: resocialisering til det grønlandske samfund. Personale fra Herstedvester bør ledsage de domfældte, således at erfaringerne fra besøgsrejserne kan udnyttes i det fortsatte arbejde.

Undersøgelsen giver ikke støtte til et forslag om oprettelse af en selvstændig anstalt for kvinder. Tværtimod synes det reelle behov for anbringelse af kvinder $i$ anstalt uhyre beskedent, når man betænker at anstaltsanbringelsen skal »anses for påkrævet for at forebygge, at tiltalte begår yderligere lovovertrædelser, eller nødvendig af hensyn til den almindelige lovlydighed«.

Materialet i denne undersøgelse vil kunne bidrage til overvejelserne omkring oprettelse af foranstaltningsmuligheder i Grønland for dem, der i dag dømmes til ophold i Anstalten i Herstedvester.

Adresse: Inge Lynge,

Speciallæge i psykiatri,

Sprydet 73, 3070 Snekkersten.

Anne Køster,

Reservelæge,

Aunstrup Plejehospital, 4000 Roskilde.

1) Lynge, Inge og Anne Koster: Den grønlandske kriminallovs bestemmelser vedrørende foranstaltninger overfor psykisk lovovertrædere.

Nordisk Tidsskrift for Kriminalvidenskab 1985 s. $243 \mathrm{ff}$.

2) Koster, Anne, Inge Lynge, Henrik Lund, Anette Rosendahl og Jens Waehrens: Psykiatriske patienter overført fra Grønland til behandling eller observation i Danmark 1978-83. (Under udarbejdelse). 